\title{
ANALISIS FAKTOR YANG MEMPENGARUHI PENINGKATAN PENDAPATAN MUSTAHIK PADA INISIATIF ZAKAT INDONESIA (IZI) DI KOTA PEKANBARU DITINJAU MENURUT EKONOMI SYARIAH
}

\author{
Muhammad Alfirman \\ Yanti \\ Yudi Irwan \\ Universitas Islam Negeri Sultan Syarif Kasim Riau \\ Email : muhammadalfirman111@gmail.com
}

\begin{abstract}
Abstrak
Zakat merupakan salah satu rukun Islam yang wajib dilaksanakan oleh mereka yang mampu, memiliki dua aspek, yaitu aspek agama dan aspek sosial. Zakat ditinjau dari aspek agama adalah ketaatan kepada Allah dan Rasul-Nya, dari aspek sosial ekonomi dapat mensejahterakan fakir miskin, oleh karena itu zakat seringkali maliyah ijtima'iyah (ibadah yang berkaitan dengan keuangan dan sosial ekonomi), tetapi fungsi zakat Kesejahteraan masyarakat akan terwujud jika zakat tidak hanya disalurkan untuk keperluan konsumtif, tetapi juga untuk tujuan produktif, dimana zakat yang diperoleh digunakan terlebih dahulu untuk menjadi usaha, yang kemudian dapat meningkatkan pendapatan dan memberikan pendapatan tetap, sehingga Tujuan utama penyaluran zakat dapat terwujud, yaitu mengubah status mustahik menjadi usaha. muszakki. Untuk itu penelitian ini merupakan penelitian lapangan yang bertujuan untuk mengetahui faktor-faktor yang mempengaruhi peningkatan mustahik, upaya yang dilakukan IZI Kota Pekanbaru dalam meningkatkan pendapatan mustahik dan tinjauan ekonomi syariah terhadap dana zakat yang disalurkan untuk meningkatkan pendapatan mustahik. Analisis data dalam penelitian ini menggunakan analisis data kuantitatif. Hasil penelitian ini menunjukkan bahwa ada beberapa hal yang meningkatkan pendapatan mustahik yaitu secara simultan keenam variabel yaitu dana zakat, peran lembaga zakat, pendidikan, lama usaha, jam kerja, lokasi usaha berpengaruh signifikan terhadap peningkatan pendapatan mustahik. pada pendapatan mustahik produktif dimana perolehan p-value adalah 0,001 $(0,001<01)$. Sedangkan secara parsial dengan menggunakan uji-t diketahui terdapat tiga variabel yang berpengaruh signifikan yaitu dana zakat, lama usaha dan jam kerja berturut-turut dengan p-value 0,044, 0,010 dan 0,002 (0,044, 0,010,0,002 < $0,1)$, sedangkan tiga variabel lainnya yaitu peran lembaga zakat, pendidikan dan lokasi usaha tidak berpengaruh signifikan terhadap pendapatan mustahik produktif dengan p-values masing-masing sebesar 0,207, 0,213 dan 0,881 (0,207, 0,213, 0,881>). 0,1). Upaya yang dilakukan Prakarsa Zakat Indonesia untuk meningkatkan pendapatan mustahik adalah melalui seleksi mustahik yang akan menerima zakat produktif, melakukan pembinaan, pelatihan dan monitoring mustahik. Kajian ekonomi syariah dalam penelitian ini sudah sesuai dengan ketentuan Al-Quran dan Hadist serta Undang-Undang Nomor 23 Tahun 2011 tentang pengelolaan zakat.
\end{abstract}

Kata Kunci : Zakat Produktif, Peningkatan Pendapatan Mustahik. 


\begin{abstract}
Zakat is one of the pillars of Islam that must be carried out by those who are able, has two aspects, namely a religious aspect and a social aspect. Zakat in terms of religious aspects is obedience to Allah and His Messenger, from the social aspect of the economy it can prosper the poor, therefore zakat is often maliyah ijtima'iyah (worship related to financial and social economics), but the function of zakat is to Welfare of the community will be realized if zakat is not only distributed for consumptive purposes, but also for productive purposes, where the zakat obtained is used first to become a business, which can then increase income and provide permanent income, so that the main purpose of zakat distribution can be realized, namely changing the status of mustahik to become a business. muszakki. For this reason, this research is a field research that aims to determine the factors that influence the increase in mustahik, the efforts made by IZI Pekanbaru City in increasing mustahik income and a sharia economic review of zakat funds channeled to increase mustahik income. Analysis of the data in this study using quantitative data analysis. The results of this study show that there are several things that increase mustahik income, namely simultaneously the six variables, namely zakat funds, the role of zakat institutions, education, length of business, working hours, business location have a significant effect on the increase in income of productive mustahis where the acquisition of the $p$-value is 0.001. (0.001 <01). While partially by using the t-test, it was found that there were three variables that had a significant effect, namely zakat funds, length of business and working hours respectively, the p-value of $0.044,0.010$ and $0.002(0.044,0.010,0.002<0.1)$, while the other three variables, namely the role of zakat institutions, education and business location do not significantly influence the income of productive mustahik with the respective $p$-values of $0.207,0.213$ and $0.881(0.207,0.213$, $0.881>0.1)$. The efforts made by the Indonesian Zakat Initiative to increase mustahik income are through selecting mustahik who will receive productive zakat, conducting coaching, training and monitoring mustahik. The sharia economic review in this study is in accordance with the provisions of the AlQuran and Hadith as well as Law No. 23 of 2011 concerning the management of zakat.
\end{abstract}

Keywords : Productive Zakat, Mustahik Income Increase.

\title{
Pendahuluan
}

Zakat merpakan salah satu dari rukun Islam yang wajib diimani oleh setiap muslim, dan hukumnya wajib untuk dilaksanakan bagi orang yang mampu. Zakat disamping tujuannya untuk mengerjakan perintah dan mendapatkan keridhoan Allah, zakat juga berperan penting dalan perekonomian Islam. Karena zakat merupakan transfer harta dari orang yang memiliki harta (muzakki) kepada orang yang berhak menerimanya (mustahik). Secara sederhana zakat merupakan transfer dari orang kaya kepada orang miskin karena didalam harta orang kaya pada hakikatnya ada hak orang miskin. Dengan demikian zakat tidak hanya berfungsi sebegai 
perwujudan ketaatan kepada Allah, tetapi juga merupakan perwujudan kepedulian kepada sesama umat manusia.

Zakat sendiri mempunyai dua pengertian: etimologi (bahasa) dan terminologi (istilah). Zakat merupakan kata dasar dari zaka yang berarti berkah, tumbuh, dan baik, menurut lisan arab kata zaka mengandung arti suci, tumbuh, berkah, dan terpuji. Sementara zakat dalam perspektif terminologi syariat adalah mensucikan jiwa dan mensucikan harta benda. Keduanya pada dasarnya mengarah pada pembersihan jiwa, tetapi yang pertama adalah menbersihkan jiwa dengan mengoptimalkan kualitas iman, dan yang kedua membersihkan jiwa dengan mendermakan sebagian harta benda. ${ }^{1}$ Zakat merupakan salah satu pilar penting dalam Islam, karenanya bagian yang tidak dapat terpisahkan dari kehidupan umat Islam, tak terkecuali di Indonesia. Namun dalam praktek, zakat yang bertujuan mulia tersebut masih dirasa jauh dari yang diharapkan dan masih gagal menjembatani jarak orang kaya dengan orang miskin dan juga untuk mengangkat kaum lemah dan yang diperlemah (Duafa' wa al-mstad'afin). Barang kali hal ini menjadi cukup alasan jika persoalan zakat selalu mencuat kepermukaan dan menjadi bahan kajian berbagai lapisan masyarakat. ${ }^{2}$

Masalah kompleks yang tidak berkesudahan di masyarakat Indonesia ini adalah masalah kemiskinan, dan kebodohan. Berawal dari kemiskinan dan kebodohan akan melahirkan keterbelakangan, kesenjangan sosial, keterpurukan, instabilitas keamanan dan kriminalitas. Tingkat kemiskinan mengalami Peningkatan. Bahkan peningkatan akibat bencana alam yang tidak terduga-duga menambah jumlah kemiskinan. Upaya pemerintah selama ini untuk mengatasi masalah kemisikinan belum dapat mengatasi masalah-masalah yang ditimbulkan oleh kemiskinan itu sendiri.

Dana zakat produktif lapak berkah yang disalurkan oleh Inisiatif Zakat Indonesia kota Pekanbaru kebanyakan adalah mustahik produktif UKM (Usaha Kecil dan Menengah), seperti pedagang kaki lima. Adapun faktorfaktor yang pempengaruhi pendapatan pedagang kaki lima menurut penelitian yang dilakukan oleh Fatmawati adalah modal, jam kerja dan pengalaman. Sedangkan dalam penelitian Arianto menyebutkan bahwa faktor yang mempengaruhi pendapatan pedangang kaki lima itu adalah modal, lama usaha, jumlah tenaga kerja, tingkat pendidikan dan lokasi. ${ }^{3}$

Jumlah masyarakat miskin di Kota Pekanbaru tahun 2016 sebanyak 27,73 juta orang atau $10,96 \%$, menurun dari tahun sebelumnya sebanyak

${ }^{1}$ Syaikh Muhammad Bin Shalih AL-Utsaimin, Sifat Zakat Nabi, (Jakarta Timur: Darus Sunnah Press, 2014), cet.ke-3, h.viii

${ }^{2}$ Gazi Inayah, Teori Komprehensip Tentang Zakat Dan Pajak, (Yogyakarta: Tiara Wacana Yogya, 2003),h.xiii

${ }^{3}$ Nurlaila Hanum, Analisis Faktor-faktor yang mempengaruhi Pendapatan Pedangan Kaki Lima, Jurnal Samudra Ekonomika, Vol 1. No 1, 2017, h. 76-77. 
28,6 juta orang atau $11,46 \%$. Dari jumlah penduduk tersebut, bahwa potensi zakat di Kota Pekanbaru sebesar Rp. 1.908.354.800.000,00 setiap tahunnya. ${ }^{4}$ Jumlah ini adalaah potensi yang sangat besar, bila dikaitkan dengan zakat fitrah dan zakat mal. Dari sisi zakat ftraah apabilaa seluruh umaat Islam Kota Pekanbaru zakat fitrah rataa-rata Rp.20.000,00 per jiwa maka akan terkumpul dan zakat fitrah sebesar Rp. 100.439.720.000,00. Dari sis zakat mal apabila $25 \%$ dari total umat Islam kota Pekanbaru atau 1.255.497 jiwa, membayar zakat mal sebesar Rp.1.200.000,00 setiap tahunnya, maka akan terkumpul zakat mal di Kota Pekanbaru setiap tahunnya sebesar Rp. 1.506.595.800.000,00.

Tabel 1. Data Jumlah Mustahik Produktif dan Muzakki di Inisiatif Zakat Indonesia (IZI) Kota Pekanbaru

\begin{tabular}{|c|c|c|c|c|c|}
\hline $\begin{array}{c}\text { Tahu } \\
\mathrm{n}\end{array}$ & $\begin{array}{c}\text { Jumlah } \\
\text { Mustah } \\
\text { ik } \\
\text { kosumt } \\
\text { if }\end{array}$ & $\begin{array}{c}\text { Jumlah } \\
\text { Mustahik } \\
\text { Produktif Lapak } \\
\text { Berkah }\end{array}$ & $\begin{array}{c}\text { Jumla } \\
\text { h } \\
\text { Muza } \\
\text { kki }\end{array}$ & $\begin{array}{c}\text { Penghimpuna } \\
\text { n dana zakat }\end{array}$ & $\begin{array}{c}\text { Penyaluran } \\
\text { dana zakat }\end{array}$ \\
\hline 2018 & 6420 & 26 & 2270 & $\mathrm{Rp}$ & $\mathrm{Rp}$ \\
\hline 2019 & 6474 & 41 & 2360 & $\mathrm{Rp}$ & $\begin{array}{c}\mathrm{Rp} \\
2.258 .196 .234 \\
1.742 .804 .80 \\
\end{array}$ \\
\hline 2020 & 8467 & 31 & 4431 & $\mathrm{Rp}$ & $\begin{array}{c}\mathrm{Rp} \\
2.804 .486 .00 \\
0\end{array}$ \\
\hline Total & 21361 & 98 & 9061 & $\mathrm{Rp} 7.198 .206 .3$ & $\begin{array}{c}\mathrm{Rp} . \\
\end{array}$ \\
& & & & 57 & $\begin{array}{c}6.237 .058 .80 \\
0\end{array}$ \\
\hline
\end{tabular}

Berdasarkan dari wawancara yang dilakukan dengan bapak Ghofur selaku staff di bidang pendayagunaan zakat produktif menjelaskan bahwasanya dari zakat produktif yang telah didistribukan Inisiatif Zakat Indonesia (IZI) kota Pekanbaru kepada para mustahik dalam bentuk modal usaha untuk mengembangkan usaha mustahik belum sepenuhnya usaha yang digeluti meraka berkembang dan belum sepenuhnya pendapatan mereka meningkat, sehingga belum sesuai dengan tujuan zakat produktif itu sendiri yaitu mengembangkan usaha mustahik sehingga pendapatan

${ }^{4}$ Artis, Strategi Pengelolaan Zakat Berbasis Pemberdayaan Masyarakat Miskin pada Badan Amil Zakat Nasional Kota Pekanbaru, Jurnal, Fakultas Dakwah dan Komunikasi UIN SUSKA Riau, Vol.1, No. 2, April 2019, h.62. 
mustahik meningkat dan tidak lagi menjadi orang yang berhak menerima zakat (mustahik) melainkan orang yang membayar zakat (muzakki).

Berdasarkan uraian latar belakang di atas, maka rumusan masalah dari penelitian ini yaitu : 1) Apa saja faktor-faktor yang mempengaruhi peningkatan pendapatan mustahik penerima zakat produktif di Inisiatif Zakat Indonesia (IZI) kota Pekanbaru. 2)Bagaimana upaya-upaya yang dilakukan oleh Inisiatif Zakat Indonesia (IZI) kota Pekanbaru untuk meningkatkan pendapatan mustahik penerima zakat produktif. 3)Bagaimana tinjauan Ekonomi Islam tentang dana zakat produktif yang diberikan untuk meningkatkan pendapatan mustahik di Inisiatif Zakat Indonesia (IZI) kota Pekanbaru.

Tujuan dari penelitian ini adalah: a)Untuk mengetahui apa saja faktorfaktor yang mempengaruhi peningkatan pendapatan mustahik penerima zakat produktif di Inisiatif Zakat Indonesia (IZI) kota Pekanbaru. b) Untuk mengetahui upaya-upaya yang dilakukan oleh Inisiatif Zakat Indonesia (IZI) kota Pekanbaru untuk meningkatkan pendapatan mustahik penerima zakat produktif. c) Untuk mengatahui tinjauan Ekonomi Islam tentang dana zakat produktif yang diberikan untuk meningkatkan pendapatan mustahik di Inisiatif Zakat Indonesia (IZI) kota Pekanbaru

Zakat secara bahasa bermakna "mensucikan, tumbuh, atau berkembang". Menurut istilah syara' zakat bermakna mengeluarkan sejumlah harta tertentu untuk diberikan kepada orang-orang yang berhak menerimanya (mustahik) sesuai dengan syarat-syarat yang telah ditentukan syariat Islam.

Sedangkan menurut terminologi para fuqaha, dimaksud sebagai penunaian, yakni penunaian hak yang wajib yang terdapat dalam harta. ${ }^{5}$ Zakat juga dimaksud sebagian harta tertentu dan diwajibkan oleh Allah untuk diberikan kepada orang-orang yang fakir. Zakat dinamakan sedekah karena tindakan itu akan menunjukkan kebenaran seorang hamba dalam beribadah dan melakukam ketaatan kepada Allah SWT.

Dari defenisi diatas dapat diketahui bahwa zakat menurut bahasa yaitu tumbuh, suci atau bersih, dan berkembang. Sedangkan menurut istilah zakat adalah mengeluarkan sebagian harta tertentu yang diberikan kepada orangorang yang berhak menerimanya (mustahik), yang tujuannya untuk mensucikan harta dan mensucikan jiwa serta menjauhkan dari keserakahan.

Menurut Kamus Besar Bahasa Indonesia produktif adalah banyak mendatangkan hasil. ${ }^{6}$ Jadi zakat produktif adalah dana zakat yang disalurkan kepada mustahik sebagai dana modal untuk usaha mustahik yang bertujuan

${ }^{5}$ Wahbah Al-Zuhayly, Penerjemah Agus Effendi dan Baharuddin Fananny, Mazhab Kajian Berbagai Mazhab, (Bandung: PT Remaja Rosdakarya), h.82-83

${ }^{6}$ M.K. Abdullah, Kamus Lengkap Bahasa Indonesia, ( Jakarta: Sandro Jaya, TT), h.380 
untuk meningkatkan ekonomi mustahik zakat. Sedangkan zakat produktif yaitu zakat yang diberikan kepada golongan tertentu (mustahik zakat) yang tujuan zakat tersebut untuk memberikan modal usaha untuk meningkatkan kesejahteraan ekonomi mustahik.

Pendapatan dalam kamus besar bahasa Indonesia adalah hasil kerja (usaha atau sebagainya). Sedangakan dalam kamus manajemen pendapatan adalah uang diterima perorangan, perusahaan dan organisasi lainnya dalam bentuk upah, gaji, sewa, bunga, komisi, ongkos dan laba. Pendapatan juga dapat diartikan sebagai penghasilan dari usaha pokok perusahaan atau penjualan barang atas jasa diikuti biaya- biaya sehingga diperoleh laba kotor.

Tingkat pendapatan mempengaruhi tingkat konsumsi masyarakat. Kenyataan menunjukan bahwa pengeluaran konsumsi meningkat dengan naiknya pendapatan, dan sebaliknya jika pendapatan turun, pengeluaran konsumsi juga turun. Tinggi rendahnya pengeluaran sangat bergantung kepada kemampuan keluarga dalam mengelola penerimaan atau pendapatannya.

Pengembangan dapat diartikan sebagai suatu usaha untuk meningkatkan kemampuan konseptual, teoritis, teknis, dan moral individu sesuai dengan kebutuhan pekerja atau jabatan melalui pendidikan dan pelatihan. Mengemukakan bahwa pengembangan UKM lebih diarahkan untuk menjadi pelaku ekonomi yang berdaya saing melalui perkuatan kewirausahaan dan peningkatan produktivitas yang didukung dengan upaya peningkatan adaptasi terhadap terhadap kebutuhan pasar, pemanfaatan hasil inovasi dan penerapan teknologi. Bisnis atau usaha adalah kegiatan atau usaha yang dilakukan untuk memperoleh keuntungan sesuai dengan tujuan dan target yang diinginkan dalam berbagai bidang, baik jumlah maupun waktunya. Pengembangan usaha adalah suatu bentuk usaha kepada usaha itu sendiri agar dapat berkembang menjadi lebih baik dan agar mencapai pada satu titik atau puncak menuju kesuksesan. Perkembangan usaha dilakukan oleh usaha yang sudah mulai terperoses dan terlihat ada kemungkinan untuk lebih maju lagi. Dan perkembangan usaha merupakan suatu keadaan terjadinya peningkatan omset penjualan. ${ }^{7}$

\section{Metode}

7 7Alyas , Muhammad Rakib, "Strategi Pengembangan Usaha Mikro, kecil Dan menengah dalam Menguatkan Ekonomi Kerakyatan (Studi Kasus Pada Usaha roti Maros di Kabupaten Maros)", Sosiohumaniora.Vol. 19. No. 2 Juli 2017, h. 115 
Adapun model konseptual yang dikembangkan dalam penelitian ini yang dibangun berdasarkan rumusan masalah dan variabel yang digunakan, yaitu sebagai berikut:

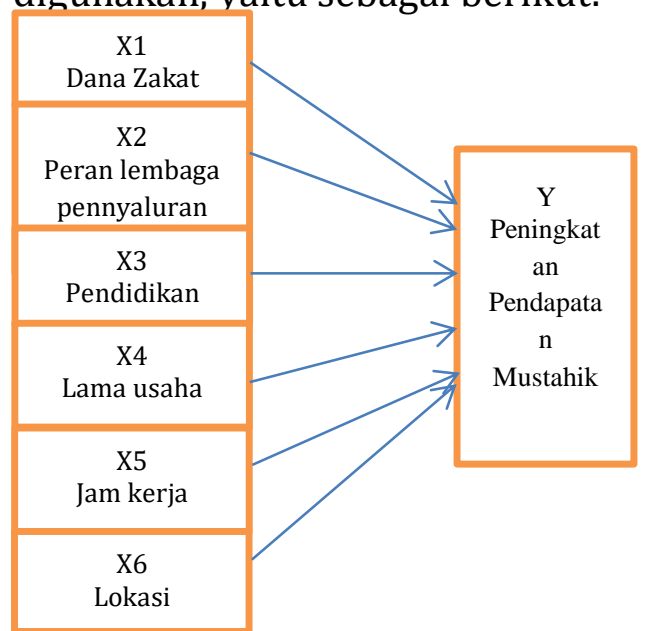

Berdasarkan skema di atas, hipotesis susunan untuk menjawab pertanyaan penelitian atas permasalahan dalam penelitian ini adalah sebagai berikut:

1) Dana zakat.

$\mathrm{H} 2$ = Dana zakat yang diberikan berpengaruh positif terhadap peningkatan pendapatan mustahik.

2) Peran Lembaga Penyaluran Zakat

H3= Peran lembaga zakat bantuan berpengaruh positif terhadap peningkatan pendapatan mustahik

3) H1= Latar belakang pendidikan berpengaruh positif terhadap peningkatan pendapatan mustahik.

4) Lama usaha

H4 = Lama usaha berpengaruh positif terhadap peningkatan pendapatan mustahik.

5) Jam kerja

H5 = Jam kerja berpengaruh positif terhadap peningkatan pendapatan mustahik.

6) Lokasi penjualan

H6 = Lokasi penjualan berpengaruh positif terhadap peningkatan pendapatan mustahik.

Penelitian ini merupakan penelitian lapangan, yaitu penelitian yang mencari sumber data primer langsung ketempat yang menjadi sasaran penelitian yaitu di kantor Inisiatif Zakat Indonesia (IZI) Kota Pekanbaru yang beralamat jalan Paus Ujung No.1B Pekanbaru.

Subjek dalam penelitian ini adalah. Pengurus Inisiatif Zakat Indonesia (IZI) Kota Pekanbaru, Sedangkan objek penelitian adalah pendistribusian zakat produktif untuk pemberdayaan ekonomi mustahik di kota pekanbaru. 
Populasi adalah keseluruhan subjek penelitian, sedangkan sampel adalah sebagian atau wakil populasi. Populasi dan sampel adaalah mustahik yang mendapatkan dana zakat produktif Lapak Berkah dari tahun 2018-2020 di kota Pekanbaru sebanyak 98 orang. Dalam hal ini peneliti menggunakan metode random sampling yaitu pengambilan sampel secara bebas atau random, artinya semua populasi mempunyai kesempatan yang sama untuk dipilih sebagai sampel. Berdasarkan perhitungan menggunakan metode random sampling, penulis mengunakan rumus slovin dengna tingkat kelonggaran 10\%, jumlah sampel yang akan diteliti sebanyak 50 orang.

\section{Hasil Dan Pembahasan}

\section{Uji Validitas}

Uji validitas dalam penelitian ini digunakan untuk mengukur valid atau tidaknya suatu kuesioner. Kriteria pengambilan keputusan untuk validitas adalah ditentukan pada $r$ hitung yang dinyatakan dengan nilai corrected item- total correlation $>r$ tabel maka indikator dikatakan valid.

Tabel 1 Uji Validitas

\begin{tabular}{|c|c|c|c|c|}
\hline Variabel & Item & r Hitung & r Tabel & Keterangan \\
\hline \multirow[t]{4}{*}{ Dana Zakat } & X.1.1 & 0.898 & 0.361 & Valid \\
\hline & X.1.2 & 0.535 & 0.361 & Valid \\
\hline & X.1.3 & 0.855 & 0.361 & Valid \\
\hline & X.1.4 & 0.921 & 0.361 & Valid \\
\hline \multirow{3}{*}{$\begin{array}{l}\text { Peran Lembaga } \\
\text { Zakat }\end{array}$} & X.2.1 & 0.813 & 0.361 & Valid \\
\hline & X.2.2 & 0.800 & 0.361 & Valid \\
\hline & X.2.3 & 0.921 & 0.361 & Valid \\
\hline \multirow[t]{3}{*}{ Pendidikan } & X.3.1 & 0.855 & 0.361 & Valid \\
\hline & X.3.2 & 0.887 & 0.361 & Valid \\
\hline & X.3.3 & 0.799 & 0.361 & Valid \\
\hline \multirow[t]{3}{*}{ Lama Usaha } & X.4.1 & 0.765 & 0.361 & Valid \\
\hline & $\mathrm{X} .4 .2$ & 0.863 & 0.361 & Valid \\
\hline & X.4.3 & 0.894 & 0.361 & Valid \\
\hline \multirow[t]{3}{*}{ Jam Kerja } & X.5.1 & 0.899 & 0.361 & Valid \\
\hline & X.5.2 & 0.956 & 0.361 & Valid \\
\hline & X.5.3 & 0.924 & 0.361 & Valid \\
\hline \multirow[t]{3}{*}{ Lokasi Usaha } & X.6.1 & 0.776 & 0.361 & Valid \\
\hline & X.6.2 & 0.772 & 0.361 & Valid \\
\hline & X.6.3 & 0.639 & 0.361 & Valid \\
\hline \multirow{2}{*}{$\begin{array}{l}\text { Peningkatan } \\
\text { Pendapatan }\end{array}$} & Y.1 & 0.522 & 0.361 & Valid \\
\hline & Y.2 & 0.881 & 0.361 & Valid \\
\hline
\end{tabular}




\begin{tabular}{|l|c|c|c|c|}
\hline & Y.3 & 0.911 & 0.361 & Valid \\
\cline { 2 - 5 } & Y.4 & 0.936 & 0.361 & Valid \\
\cline { 2 - 5 } & Y.5 & 0.868 & 0.361 & Valid \\
\cline { 2 - 5 } & Y.6 & 0.698 & 0.361 & Valid \\
\cline { 2 - 5 } & Y.7 & 0.405 & 0.361 & Valid \\
\hline
\end{tabular}

Berdasarkan tabel diatas dapat dilihat hasil dari uji validitas menunjukkan bahwa nilai $r$ hitung dari masing-masing variabel lebih besar dari nilai $r$ tabel sebesar 0.361 . Jadi dapat disimpulkan bahwa masing-masing butir pernyataan dalam kuesioner adalah valid.

\section{Uji Reabilitas}

hasil uji reabilitas dapat dilihat pada tabel berikut.

Tabel 2 Uji Reabilitas

\begin{tabular}{|l|c|c|c|}
\hline \multicolumn{1}{|c|}{ Variabel } & $\begin{array}{c}\text { Reliability } \\
\text { Coefficients }\end{array}$ & $\begin{array}{c}\text { Cronbach's Alpha } \\
\text { Based on } \\
\text { Standardized } \\
\text { Item }\end{array}$ & Keterangan \\
\hline Dana Zakat & 4 Item & 0.803 & Reliabel \\
\hline $\begin{array}{l}\text { Peran Lembaga } \\
\text { Zakat }\end{array}$ & 3 Item & 0.800 & Reliabel \\
\hline Pendidikan & 3 Item & 0.830 & Reliabel \\
\hline Lama Usaha & 3 Item & 0.790 & Reliabel \\
\hline Jam Kerja & 3 Item & 0.917 & Reliabel \\
\hline Lokasi Usaha & 3 Item & 0.546 & Reliabel \\
\hline Pendapatan & 7 Item & 0.871 & Reliabel \\
\hline
\end{tabular}

Berdasarkan tabel diatas menunjukkan variabel dana zakat, peran lembaga zakat, pendidikan, lama usaha dan lokasi usaha memiliki nilai cronbach's alpha based on standardiezed lebih besar dari nilai $r$ tabel yaitu 3.61 sehingga instrumen yang dalam penelitian reabilitas pernyatan baik.

\section{Uji Normalitas}

Uji normalitas bertujuan untuk menguji apakah model regresi, dan apakah residual memiliki distribusi normal. Pengujian normalitas data dengan menggunakan uji Kolmogorov-Smirnov. Apabila nilai sig. Kolmogorov-Smirnov berada diatas 0.05 maka dapat disimpulkan bahwa data telah terdistribusi normal. Berikut hasil Pengujian normalitas mengggunakan Uji Kolmogorov-Smirnov :

\section{Tabel 3 Uji Normalitas}

One-Sample Kolmogorov-Smirnov Test 


\begin{tabular}{|ll|r|}
\hline & & Standardized Residual \\
\hline N & Mean & 50 \\
Normal & Std. & \\
& Deviati & \\
& on & \\
Most Extreme & Absolut & \\
Differences & e & .93677693 \\
& Positive & \\
& Negativ & .118 \\
& e & .118 \\
Kolmogorov-Smirnov Z & -.108 \\
Asymp. Sig. (2-tailed) & .832 \\
\hline
\end{tabular}

a. Test distribution is

Normal

Data penelitian yang digunakan dikatakan berdistribusi normal apabila apabila nilai Asymp. Sig. (2-tailed) lebih besar dari $\alpha=0,1$. Berdasarkan Tabel 4.6 di atas, nilai Asymp. Sig. (2-tailed) dari model persamaan yang diuji sebesar 0,493 lebih besar dari 0,1. Hal ini menunjukkan data yang digunakan dalam penelitian ini telah berdistribusi normal.

\section{Uji Multikolinearitas}

Uji multikolinearitas bertujuan untuk menguji apakah model regresi ditemukan adanya korelasi antara variabel bebas (Independen). Model regresi yang baik seharusnya tidak terjadi korelasi antara variabel independen. Uji multikolinearitas dilakukan dengan melihat nilai tolerance dan variance inflation factor (VIF) dari hasil analisis dengam menggunakan SPSS. Apabila nilai VIF lebih tinggi dari <10, maka dapat disimpulkan tidak terjadi multikolinearitas. Berikut hasil pengujian multikolinearitas seperti tampak pada tabel berikut : 


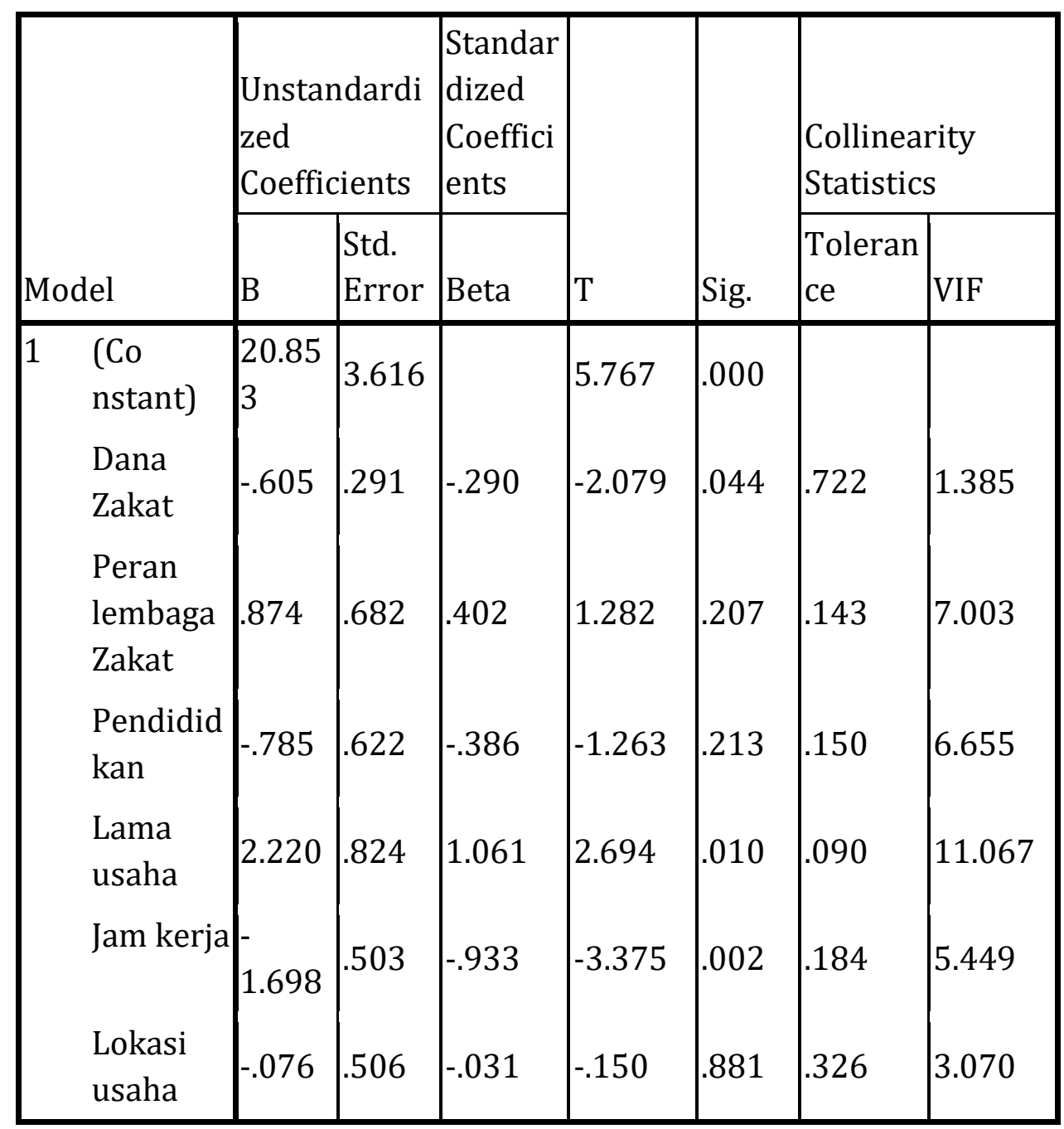

a. Dependent Variable:

Pendapatan

apat

dilihat pada tabel diatas nilai variance inflation factor (VIF) semua variabel penelitian $<10$ artinya pengujian ini bebas dari masalah multikolinearitas. Dan pengujian dapat dilanjutkan.

\section{Uji Heteroskedastitas}

Uji Heteroskedastitas betujuan untk menguji apakah dalam model regresi terjadi ketidaksamaan varian dari satu pengamatan ke pengamatan lain. Jika variansi residual satu pengamatan ke pengamatan lain tetap maka disebut homoskedastisitas dan jika berbeda disebut heteroskedatisitas. Model regresi yang baik adalah yang homoskedatisitas. Pengujian 
heteroskedastisitas dalam penelitian ini menggunakan histogram scaterplott. $^{8}$

Dimana sumbu horizontal menggambarkan nilai predicted standardized sedangkan sumbu pertikal menggambarkan nilai residual studentized. Jika scaterplott membentuk pola tertentu, hal itu menunjukkan adanya masalah heteroskedastisitas pada model regresi yang dibentuk. Sedangkan jika scaterplott menyebar secara acak maka hal itu menunjukkan tidak terjadinya masalah heteroskedastisitas pada model regresi yang dibentuk. Adapun hasil uji heteroskedatisitas sebagai berikut:

\section{Gambar 1 Uji Heteroskedastitas}

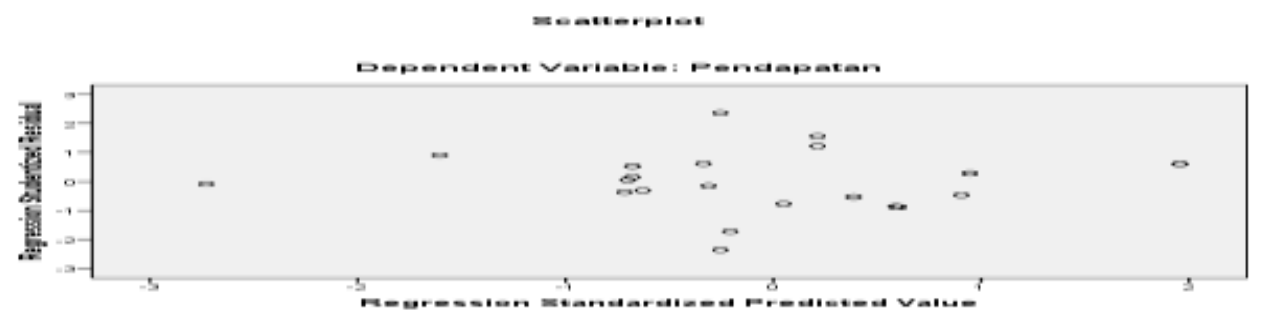

Dapat dilihat pada gambar diatas, titik histogram scatterplot tersebar dibawah dan diatas titik 0 dan tidak membentuk pola tertentu, artinya pengujian ini bebas dari masalah heterokodesitas.

\section{Analisis Regresi Liner Berganda}

Analisis dalam penelitian ini mengunakan model regresi linier berganda, dimanaa dalam analisis regresi tersebut akan menguji pengaruh dana zakat, peran lembaga zakat, lama usaha, jam kerja dan likasi usaha terhadap tingkat pendapatan mustahik. Pengelolaan data menggunaakan SPSS berdasarkan data-data yang diperoleh dari responden berjumalah 50 sampel penelitian yang dilakukan.

8 Imam Ghozali, Aplikasi Analisis Multivariate dengan Program IBM SPSS 23, (Semarang: Badan Penerbit Universitas Diponogoro), h. 42. 
Tabel 5 Analisis Regresi Berganda

Coefficients ${ }^{\mathbf{a}}$

\begin{tabular}{|c|c|c|c|c|c|}
\hline \multirow[b]{2}{*}{ Model } & \multicolumn{2}{|c|}{$\begin{array}{l}\text { Unstandardized } \\
\text { Coefficients }\end{array}$} & \multirow{2}{*}{$\begin{array}{c}\begin{array}{c}\text { Standardized } \\
\text { Coefficients }\end{array} \\
\text { Beta }\end{array}$} & \multirow[b]{2}{*}{$\mathrm{t}$} & \multirow[b]{2}{*}{ Sig. } \\
\hline & B & $\begin{array}{l}\text { Std. } \\
\text { Error }\end{array}$ & & & \\
\hline $1 \quad$ (Constant) & 20.853 & 3.616 & & 5.767 & .000 \\
\hline Dana zakat & -.605 & .291 & -.290 & -2.079 & .044 \\
\hline $\begin{array}{l}\text { Peran lembaga } \\
\text { zakat }\end{array}$ & .874 & .682 & .402 & 1.282 & .207 \\
\hline Pendidikan & -.785 & .622 & -.386 & -1.263 & .213 \\
\hline Lama usaha & 2.220 & .824 & 1.061 & 2.694 & .010 \\
\hline Jam kerja & -1.698 & .503 & -.933 & -3.375 & .002 \\
\hline Lokasi usaha & -.076 & .506 & -.031 & -.150 & .881 \\
\hline
\end{tabular}

a. Dependent Variable:

Pendapatan

Berdasarkan hasil yang diperoleh dari rekapitulasi hasil analisis regresi linear berganda berdasarkan pada hasil analisis koefisien regresi pada Tabel diatas adalah sebagai berikut:

$Y=20.853-0.605 X 1+0.874 X 2-0.785 X 3+2.220 X 4-1.698 X 5-0.076 X 6$

Model regresi tersebut mengandung arti:

a. Nilai konstanta 20.853 menunjukkan bahwa dana zakat, peran lembaga zakat, pendidikan, lama usaha, jam kerja dan lokasi usaha sama dengan nol maka tingkaat pendapatan mustahik akan meningkat sebesar 20.853.

b. Nilai koefisien regresi X1 (Dana Zakat) sebesar -0.605 menunjukkan bahwa bila ada penambahan variabel dana zakat satu satuan, maka tingkat pendapatan mustahik (Y) akan mengalami penurunan sebesar 0.605 satuan dengan asumsi variabel lainnya konstan.

c. Nilai koefisien regresi X2 (Peran Slembaga zakat) sebesar 0.874 menunjukkan bahwa setiap pembinaan lembaga zakat naik satu satuan, maka pendapatan mustahik akan mengalami peningkatan sebesar 0.874 satuan dengan asumsi variabel lainya konstan.

d. Nilai koefisien regresi X3 (Pendidikan) sebesar -0.785 menunjukkan bahwa semakin tinggi pendidikan mustahik, maka tingkat pendapatan mustahik akan mengalami penurunan sebesar $-0,785$ satuan dengan asumsi variabel lainnya konstan.

e. Nilai koefisien regresi X4 (Lama usaha) sebesar 2.220 menunjukkan bahwa semakin lama usaha yang dilakukaan oleh mustahik, maka 
semakin meningkaat pendapatan mustahik sebesar 2.220 satuan dengan asumsi variabel lain konstan.

f. Nilai koefisien regresi X5 (Jam kerja) sebesar -1.698 menunjukkan bahwa semakin bertambah jam kerja, maka semakin tingkat pendapatan mustahik akan menurun sebesar -1.698 satuan dengan asumsi variabel yang lainnya konstan.

g. Nilai koefisien regresi X6 (Lokasi usaha) sebesar -0.076 menunjukkan bahwa bila X6 naik satu satuan, makan tingkat pendapatn mustahik akan menurun sebesar -0.076 satuan dengan asumsi variabel lainnya konstan.

\section{Pembahasan}

a. Pengaruh Dana Zakat terhadap Peningkatan Pendapatan Mustahik

Hasil t hitung dana zakat sebesar -2.079 dengan signifikan 0,044. Maka dapat disimpulkan hipotesis pertama yang menyatakan bahwa dana zakat mempengaruhi peningkatan pendapatan terbukti kebenarannya. Hasil ini sejalan dengan hasil penelitian Hafido (2015) bahwa dana zakat produktif memiliki pengaruh positif terhadap tingkat pendapatan. Hal ini disebabkan karena dengan dana zakat produktif yang dilasurkan dimanfaatkan sebagai tambahan modal bagi usaha mustahik, dan dengan modal tersubut digunakan untuk memenuhi kebutuhan-kebutuhan dalam menjalankan usaha yang dilakukan.

Jika mustahik produktif tersebut tidak menggunakan dana zakat untuk menambah modal usaha, malahan digunakan untuk konsuntif, maka dana zakat tersebut tidak aakan berpengaruh terhadap peningkatan mustahik.

b. Pengaruh Peran Lembaga Zakat terhadap Peningkatan Pendapatan Mustahik

Hasil t hitung peran lembaga zakat sebesar 1.282 dengan nilai signifikan 0,207. Maka dengan demikian hipotesis variabel ini ditolak dengan menunjukan bahwa nilai $t$ hitung tidak signifikan. Hal ini berarti peran lembaga zakat tidak berpengaruh terhadap peningkatan pendapatan mustahik. Hal ini sejalan dengan hasil penelitian Annisa (2014), yang mendapati bahwa pelatihan ataupun pendampingan yang dilakukan oleh lembaga pengelola zakat tidak memiliki pengaruh terhadap peningkatan pendapatan mustahik. Hal ini disebabkan kurangnya pendampingan yang dilakukan oleh pihak lembaga pengelola zakat.

c. Pengaruh Pendidikan terhadap Peningkatan Pendapatan Mustahik

Hasil t hitung variabel pendidikan sebesar -1.263 dengan nilai sigifikan 0,213. Maka dengan demikian menunjukan bahwa nilai $t$ yang diperoleh tersebut tidak signifikan karena lebih besar dari 0,1 
$(0,213>0,1)$. Dengan demikian dapat dikatakan bahwa pendidikan tidak mempengaruhi peningkatan pendapatan mustahik. Hasil ini sejalan dengan hasil penelitian Indra (2016) yang menyatakan bahwa tingkat pendidikan mustahik tidak mempengaruhi peningkatan pendapatan mustahik, dikarenakan rata-rata latar belakang pendidikan mustahik kurang lebih sama, dan mereka bekerja juga dibidang yang tidak menggunakan jenjang karir sehingga latar belakang pendidikan tidak terlalu mempengaruhi peningkatan pendapatan mereka.

d. Pengaruh Lama Usaha terhadap Peningkatan Pendapatan Mustahik

Hasil penelitian ini menunjukkan bahwa adanya pengaruh lama usaha terhadap pendapatan mustahik. Hal tersebut terlihat dari hasil yang diperoleh nilai thitung sebesar 2.694 sedangkan nilai t tabel sebesar 1.301 dan nilai signifikasi uji t yakni nilai p-value sebesar 0.010 lebih kecil dari $\alpha=0.1$ serta nilai koefisien regresi sebesar 2.220. Ini berarti bahwa lama usaha berpengaruh terhadap peningkatan pendapatan mustahik.

e. Pengaruh Jam Kerja terhadap Peningkatan Pendapatan Mustahik

Berdasarkan hasil penelitian yang menunjukkan adanya pengaruh jam kerja terhadap pendapataan mustahik. Hal tersebut dapat dilihat dari perolehan nilai t hitung sebesar -3.375 sedangkan nilai t tabel sebesar 1.301 dan nilai signifikasi uji t yakni nilai p-value sebesar 0.002 lebih kecil dari $\alpha=0.1$ serta nilai koefisien regresi sebesar 0.503 . Ini berarti bahwa jam kerja berpengaruh terhadap peningkatan pendapatan mustahik. Semakin tinggi jam kerja yang digunakan untuk menjalan usaha maka semakin bersar pula pendapatannya.

f. Pengaruh Lokasi Usaha terhadap Peningkatan Pendapatan Mustahik

Berdasarkan hasil penelitian yang menunjukkan bahwa lokasi usaha tidak berpengaruh terhadap peningkaatan pendapan mustahik. Hal ini dapat di lihat perolehan nilai t hitung sebesar -0.150 sedangkan nilai $t$ tabel sebesar 1.301 dan nilai signifikasi uji t yakni nilai $\mathrm{p}$-value sebesar 0.881 lebih besar dari $\alpha=0.1$ serta nilai koefisien regresi sebesar -0.076 . Ini berarti bahwa peran lokasi usaha tidak berpengaruh terhadap peningkatan pendapatan mustahik.

\section{Kesimpulan}

Berdasarkan hasil analisi yang telah dilakukan, maka dapat ditarik kesimpulaan sebagai berikut:

1. Setelah melakukan analisis regresi melalui uji-f, diketahi bahwa secara simultan keenam variabel yaitu dana zakat, peran lembaga zakat, pendidikan, lama usaha, jam kerja, lokasi usaha berpengaruh secara 
signifikan terhadap peningkatan pendapatan mustahi produktif diman perolehan $p$-value nya sebesar $0.001(0.001<01)$. Sedangakan secara persial dengan menggunakan uji-t, diperoleh bahwa terdapat tiga variabel yang berpengaruh secara signifikan, yaitu dana zakat, lama usaha dan jam kerja masing-masing nilai $p$-value sebesar 0.044, 0.010 dan 0.002 $(0.044,0.010,0.002<0.1)$, sedangkan tiga variabel lainnya yaitu peran lembaga zakat, pendidikan dan lokasi usaha tidak berpengaruh secara signifikan terhadap pendapatan mustahik produktif dengan nilai masingmasing nilai $p$-value nya sebesar $0.207,0.213$ dan $0.881(0.207,0.213$, $0.881>0.1$ ).

2. Upaya-upaya yang dilakukan oleh Inisiatif Zakat Indonesia (IZI) kota Pekanbaru untuk meningkatkan pendapatan mustahik penerima zakat produktif adalah pertama memilih mustahik yang akan diberikan dana zakat dan membuat perjanjian dengan mustahik agar dana zakat produktif tersebut dipergunkan dengan ebaik-baiknya, kedua melakukan pemembinaan dan pelatihan kepada mustahik produktif, ketiga melakukan pengawasan kepada mustahik selama satu tahun.

3. Tinjauan Ekonomi Islam tentang dana zakat produktif yang diberikan untuk meningkatkan pendapatan mustahik di Inisiatif Zakat Indonesia (IZI) kota Pekanbaru adalah sudah sesuai dengan ketentuan Al-Quran dan Hadis serta undang-undang Nomor 23 Tahun 2011 tentang pengelolaan zakat.

\section{Daftar Pustaka}

Abd Shomad, Hukum Islam, Jakarta:Kencana, 2012.

Abdul Halim Hasan, Tafsir Al-Ahkami, Jakarta: Kencana Prenada Media Group, 2011.

Adi Wahyudi, Pengembangan Usaha Home Industri Bakso Fatin di Desa Koto Mesjid Dalam Meningkatkan Pendapatan Pengusaha Dan Karyawan Ditinaju Menurut Ekonomi Islam, (Pekanbaru: Fakultas Syariah Dan Hukum, 2016.

Akhmad Mujahidin, Ekonomi Islam II Pasar, Perdagangan, Manajemen, Produksi, Konsumsi, Distribusi Keuangan, dan Konstribusi, Pekanbaru: AlMujtahadah Press, 2014.

Al Bani, Muhammad Nashiruddin, Penerjemah Imron Rosadi, Ringkasan Shahih Muslim 1, Jakarta Selatan: Pustaka Azzam, 2007.

Alyas , Muhammad Rakib, "Strategi Pengembangan Usaha Mikro, kecil Dan menengah dalam Menguatkan Ekonomi Kerakyatan (Studi Kasus Pada Usaha roti Maros di Kabupaten Maros)", Sosiohumaniora.Vol. 19. No. 2 Juli 2017.

Andri Soemitra, Bank Dan Lembaga keuangan Syariah, Jakarta: Kencana Prenada Media Group, 2012. 
Arif Yusuf Hamali, Pemahaman Strategi Bisnis Dan Kewirauahaan, Jakarta: Pranadamedia Group, 2016.

Arikunto Suharsima, Manajemen Penelitian, Jakarta: PT Rineka Cipta, 2010.

Case, Karl dan Fair, Ray, Prinsip-prinsip Ekonomi, Jakarta: Erlangga, 2007

Depertemen Agama, Al-Qur'anul Karim, Depok: Cahaya Qu'an, 2013.

Eko Suprayitno, Ekonomi Islam, Yogyakarta: Graha Ilmu, 2005.

Euis Amelia, Sejarah pemikran Ekonomi Islam dari Masa Klasik Hingga Kontemporer, Depok: Gramata Publishing, 2010.

Gazi Inayah, Teori Komprehensip Tentang Zakat Dan Pajak, Yogyakarta: Tiara Wacana Yogya, 2003.

Gusfahmi, Pajak Menurut Syariah, Padang, TP, 2010.

Hertina, Problematika Zakat Propesi Dalam Produk Hikim di Inndonesia, Pekanbaru: Suska Press, 2013.

Idri, Hadis Ekonomi Ekonomi dalam Perspektif Hadis Nabi, Jakarta: Prenada Media Group, 2016.

Imam Ghozali, Aplikasi Analisis Multivariate dengan Program IBM SPSS 23, Semarang: Badan Penerbit Universitas Diponogoro

Inisiatif Zakat Indonesia, Laporan Tahunan 2016 Inisiatif Zakat Indonesia, TT: $\mathrm{TP}, 2016$.

Jariba bin Ahmad Al-Haritsi, Penerjemah Asmuni Solihan Zamakhasyari, Fikih Ekonomi Umar bin Khattab, Jakarta Timur, khalifah, 2006.

Jemmy Rumengan dan Adham, Metode Penelitian Kualitatif dan Kuantitatif, Bandung: Cita Pustaka Media, 2015

M. Iqbal Dawami, saatnya Menjadi Pengusaha, Jakarta: gramedia, 2013.

M.Ali Hasan, Zakat Pajak, Asuransi dan Lembaga Keuanga, Jakarta: PT. Raja Grafindo Persada, 1997.

M.Arif Mufraini, Akuntansi dan Manajemen Zakat Mengomunikasikan Kesadaran dan Membangun Jaringan, Jakarta: Kencana Prenada Media Group, 2006.

M.K. Abdullah, Kamus Lengkap Bahasa Indonesia, Jakarta: Sandro Jaya, TT

M.K. Abdullah, Kamus Lengkap Bahasa Inodinesia, Jakarta : Sandro Jaya, TT.

Mardani, Fiqh Ekonomi Syariah, Jakarta: Kencana, 2012.

Mawardi, Ekonomi Islam, Pekanbaru: Alaf Riau, 2007.

Muh. Said, pengantar Ekonomi Islam, Pekanbaru: Suska Press, 2008.

Muhammad Bin Shahih Al-Utsamin, Syarh Shahih Al-Bukhari, Penerjemah Abu Ihsan Al-Atsari, Syarah Sahih Al-Bukhari, Jakarta Timur: Darus Sunnah Press, 2013

Muhammad Daud Ali, Sistem Ekonomi Islam Zakat Dan wakaf, Jakarta: UI Press, 2012.

Muhammad Nashiruddin Al-Bani, Mukhtashar Shahih Muslim, Penerjemah Elly Lathifah, Al- Maktab Al-Islami, 2007

Mulyadi. Sistem Akuntansi, Edisi ke-3, Cetakan ke-5. Penerbit Salemba. Empat, 2010

Mursyidi, Akuntansi Zakat Kontemporer, Bandung: PT Remaja Rosdakarya, 2003

Nurul Huda, Lembaga Keuangan Islam Tinjauan Teoritis dan Praktek, Jakarta: Kenca Prenada Media Group, 2015 
Purdi E. Chandra, trik Sukses Menuju Sukses, Yogyakarta: Grafika Indah, 2000

Ridwan dan Ahmad Hasan, Manajemen BMT Bandung: CV Pustaka Setia

Sadono Sukirni: Makro Ekonomi, Jakarta: Raja Grafindo Persada, 2006

Sapiudin Shidiq, Fikih Kontemporer, Jakarta: Kencana, 2016

Sri Nurhayati, dan Wasilah, Akuntansi Syariah dI Indonesia, Jakarta: Salemba Empat, 2015

Sugiyono, Metode Penelitian Bisnis, Bandung: CV Alfabeta, 2013

Tim Darul Ilmi, Buku Panduan LengkapAgama Islam, Jakarta, Qultum Media, 2010

Wahbah Al-Zuhayly, Penerjemah Agus Effendi dan Baharuddin Fananny, Mazhab Kajian Berbagai Mazhab, Bandung: PT Remaja Rosdakarya

Yusuf Qardhawi , Penerjemah Dadang Sobar, Shadaqah Cara Islam Mengentaskan Kemiskinan, Bandung: PT Remaja Rosdakarya, 2013

Zulkifli, Panduan Praktis Pintar Memahami Zakat, Pekanbaru: Suska Press

Akbar Syam, Peran Badan Amil Zakat dalaam Membina Mustahik menjadi Muzakki (studi Kasus Pada BAZNAS Kabupaten Maros), Jurnal Al-Qoda'U Peradilan dan Hukum Keluaarga Islam, Pascasarjana UIN Alauddinj Makasar, Tahun 2020.

Fatmawati dkk, 2014, Analisis Faktor yang Mempengaruhi Pendapatan Pedangang Kaki Lima di Pasar Raya Padang, Jurnal Pendidikan Ekonomi, Sekolah Tinggi Keguruan dan Ilmu Pendidikan Sumatra Barat

Hamzah, Pendayagunaan Zakat pada Badan Amil Zakat Nasionala Dalam Meningkatkan Kesejahteraan Umat, Disertasi, Sekolah Pascasarjana Universitas Islam Negeri Syarif Hidayatullah Jakarta, 2009.

Muammad Akhri Amir, Pemanfaatan Zakat Produktif serta Pengaruhnya Terhadap Tinggat Pendapatan Mustahik di Kota Makasar (Studi Kasus BAZNAS Kota Makasar), Tesis, UIN Suan Kalijaga Yogayakarta, 2017.

Nurlaila Hanum, Analisis Faktor-faktor yang mempengaruhi Pendapatan Pedangan Kaki Lima, Jurnal Samudra Ekonomika, Vol 1. No 1, 2017

Setia Ningsih dan Hendra dukalang, Penerapan Metode Suskesif Interval pada Analisis Regresi Liniear Berganda, Jumbara Journal of Mathematics, Volume 1 Nomor 1 Tahun 2019

Rebon Taufil Hidaya, Sri Zuliarni, Pengaruh Lokasi Usaha Pada Volume Penjualan, Jurnal Akuntansi dan Bisnis Uneversitas Riau, Vol 9, No 2, Juli 2014.

Rusli, Abubakar Hamzah dan sofyan Syahnur, Analisi Dampak Pemberiah Modal Zakat Produktif Terhadap Pengentaskan Kemiskinan di Kabupaten Aceh Utara, Jurnal Pascasarjan Universitas Syah Kuala, Vol. 1, No, 1 Februari 3013.

Sudarmanto, Kinerja dan Pengembangan Kompensi SDM (Teori, Demensi Pengukuran dan Implementasi dalam Organisasi, Yogyakaarta: Pustaka Pelajar, 2009 